\title{
Research on the allelopathic effect among the species Tanacetum vulgare and some agricultural crops
}

\author{
Hodişan Nicolae - Csep Nicolae \\ University of Oradea, Faculty of Environmental Protection \\ hodisann@yahoo.com
}

SUMMARY

\begin{abstract}
The research presents the results of the allelophatic effect upon the germination and growth of plants, immediately after springing, viewed as the interaction between the species of Tanacetum vulgare sin Chrysanthemum vulgare and three other crops: wheat (Triticum aestivum L.), barley (Hordeum vulgare L.), rape (Brassica napus ssp. oleifera L.). The experiments that were performed consisted in applying treatments with aqueous extracts obtained from the roots, leaves, stems and flowers harvested from $T$. vulgare plants upon the seeds of the three agricultural crops mentioned before. In all aqueous extracts, the results indicate the presence of some chemical compounds that have inhibiting allelophatic effect. The plants upon which tests were made showed great sensitivity, the results on their germination and growth being significantly negative and highly significantly negative.

The conclusions of this research sustain the idea of setting new research objectives in order to discover the chemical compounds from T. vulgare extracts that have such a stong effect and the possibilities they offer.
\end{abstract}

Keywords: allelopathy, Tanacetum vulgare, wheat,barley,rape

\section{INTRODUCTION}

Tanacetum vulgare (syn: Chrysanthemum vulgare) is a herbaceous species, common in the whole country, widely spread in the plain and hill area, ruderally, throughout pastures or meadows.

This species is found both in old folk medicine as a remedy for headaches, stomach aches, diarrhoea, liver diseases, typhus, intestinal parasites, and in modern medicine, the latter using the vegetal extracts to prepare some pharmaceutical products (Giardinophyt) with antihelminthic effect (www.sfaturimedicale.ro).

The extracts, infusions and decoctions obtained from different vegetative organs have an insecticide effect upon the homopterous insects that harm fruit and vegetable cultures, and that is why it is advisable to use them in organic agriculture (Ciceoi 2005).

Because of T. vulgare's phytopharmaceutical properties, a research seemed opportune in order to determine the presence in the vegetative organs of the plant (roots, leaves, stems and flowers) of the allelopathic compounds and their effect in the interaction with some agricultural plant species.

The allelopathy describes the field that studies the contradictory relationships between different plant species, as well as those between the individuals of the same species. The chemical compounds that are involved in the interactions between plants are generally called allelopathic substances and play an important part in the primary metabolic processes, essential for the survival of the plants (Rice 1974).

Chemical substances released by the plant in the environment produce the allelopathic effects. The predominant allelochemicals are the alkaloids, the phenols, terpenoids and glycosides. The majority of allelochemical substances are initially found in the body of the plants, in an inactive form. Due to subsequent transformations hydrolysis, oxydoreduction, methylation and dimethylation, etc., new products are generated that have special allelopathic properties (Whittaker and Feny 1971, cited by Corbu 2007).

According to some authors Calera and collaborators 1995; Einhellig 1995 and 1999; Blum and collaborators 1999; Reigosa and collaborators 1999; Macias and collaborators 1999, the allelopathic compounds affect the cellular division of rival plants, the activity of phytohormons, the functional efficiency of chloroplasts and mitochondria, the enzyme dynamics, the functions of biomembranes, the relationship plant-water and other different plant processes. The idea regarding the influence of some chemical substances released in the environment by certain organisms upon other neighbouring organisms was issued by De Condolle in 1832 . He concluded that all the plants secrete through their roots certain substances that can stimulate or inhibit the growth of other plants.

In 1937, Molisch had published the results of the research concerning the action of ethylene upon some superior plants, phenomenon that he later named "Allelopathie". He was the one who defined for the first time the term of allelopathy, meaning at that time, the biochemical interactions established between all types of plants, including in this notion both the harmful and the stimulating interactions (Uludag and collaborators. 2006).

A real breakthrough in understanding the allelopathy phenomenon happened in 1974 as a consequence to the publishing of Rice's book, "Allelopathy", in which the author defined allelopathy as being the toxic effect of a plant upon another one by producing some chemical compounds which are released and diffused in the environment (Hodişan 2009). 
The results of the research concerning similar studies to those presented in this paper showed that the species $X$. strumarium secretes allelochemical compounds that influence both the germination of the seedes and the growth of vegetative mass in culture plants and weeds (Bozsa and Oliver 1993; Sondhia and Saxena 2003; Sinha and Samart 2004; Dávid and collaborators. 2005; Tanveer and collaborators 2008).

\section{MATERIALS AND METHODS}

There were harvested green $T$. vulgare plants from which there were collected the vegetative organs, leaves, roots, stems and flowers, but there were also used dehydrated mature plants from which there were collected only the leaves.

To prepare the aqueous extracts, $100 \mathrm{~g}$ of vegetal material (roots, stems, leaves, dehydrated leaves and fruits) were scaled, minced and macerated in $500 \mathrm{ml}$ of distilled water for 48 hours at room temperature, more precisely at $22-25^{\circ} \mathrm{C}$. The preparation obtained was decanted and filtered and then preserved until usage in the dark, at 4$5^{\circ} \mathrm{C}$.

The allelopathic effect of aqueous extracts on seed germination and growth of plants immediately after springing in different species cultivated in spring, autumn or late summer was studied: wheat (Triticum aestivum L.), barley (Hordeum vulgare L.), rape (Brassica napus L.).

The seeds of the crop species studied were put to germinate, by 100 seeds, in ceramic pots, in sand. The germination substratum was obtained by calcining the sand in the drying oven at $180-200^{\circ} \mathrm{C}$, then sifting it through $0.3 \mathrm{~mm}$ sieves in order to standardize the granulation and then rehydrating it by adding $100 \mathrm{ml}$ aqueous extract to $1000 \mathrm{~g}$ sand. For each germination pot were used equal quantities of sand in order to maintain the depth laying of the seeds at $1 \mathrm{~cm}$.

The same method was applied to the control sample variant with the difference that for rehydrating the sand distilled water was used.

The seed germination took place at $22-25^{\circ} \mathrm{C}$, in natural light, with the specific diurnal variations.

Three repetitions were made for each experimental variant.

The reading of the results for establishing the germination energy took place four days after the germination and consisted in counting the sprouted seeds, but the reading of biometrical determinations took place only after seven days by measuring the height of the plants.

The data obtained through observation and measurements was interpreted statistically.

\section{RESULTS AND DISCUSSIONS}

\section{Results obtained on wheat (Triticum aestivum L.)}

After applying treatments with leaf and flower aqueous extracts obtained from $T$. vulgare species, a strong inhibiting effect on the germination of wheat seeds was observed (variants E3 and E5), more precisely the germination percentage was of only $18.3 \%$ in the case of leaf extracts and of $14.5 \%$ in the case of flower extracts. In these cases the results indicate highly significant negative differences compared to the control sample (Table 1).

In root and stem aqueous extracts (variants E2 and E4) the germination percentage compared to the control sample was of $84.7 \%$ in the case of root extracts and of $90.1 \%$ in stem extracts. In these cases the results indicate highly significant negative differences in variant E2 and distinctly significant ones in variant E4.

Table 1

The Influence of Tanacetum vulgare extract on the Germination of Wheat Seeds (Triticum aestivum L.)

\begin{tabular}{|c|c|c|c|c|c|c|}
\hline Symbol & $\begin{array}{l}\text { Type of } \\
\text { Extract }\end{array}$ & $\begin{array}{c}\text { Number of } \\
\text { Germinated } \\
\text { Seeds } \\
\end{array}$ & $\begin{array}{c}\text { Percent of } \\
\text { Germinated } \\
\text { Seeds } \\
\end{array}$ & $\begin{array}{c}\text { Difference } \\
(\%)\end{array}$ & $\begin{array}{l}\text { Significance of } \\
\text { Differences }\end{array}$ & $\begin{array}{l}\text { The Duncan } \\
\text { Classification }\end{array}$ \\
\hline E1 & Control sample & 87.33 & 100.0 & 0.00 & Mt. & $\mathrm{C}$ \\
\hline E2 & Roots & 74.00 & 84.7 & -13.33 & 000 & $\mathrm{~B}$ \\
\hline E3 & Leaves & 16.00 & 18.3 & -71.33 & 000 & $\mathrm{~A}$ \\
\hline E4 & Stems & 78.67 & 90.1 & -8.67 & 00 & $\mathrm{~B}$ \\
\hline E5 & Flowers & 12.67 & 14.5 & -74.67 & 000 & $\mathrm{~A}$ \\
\hline \multirow{3}{*}{\multicolumn{4}{|c|}{$\begin{array}{l}\text { SD (p 5\%) } \\
\text { SD (p 1\%) } \\
\text { SD (p 0.1\%) }\end{array}$}} & 5.51 & & \\
\hline & & & & 8.01 & & \\
\hline & & & & 12.02 & & \\
\hline
\end{tabular}


The Influence of Tanacetum vulgare extract on the Height of Wheat Plants (Triticum aestivum L.) after Springing

\begin{tabular}{|c|c|c|c|c|c|c|}
\hline Symbol & Type of Extract & $\begin{array}{c}\text { Height of } \\
\text { Plants } \\
\text { (cm) }\end{array}$ & $\begin{array}{c}\text { Height of } \\
\text { Plants } \\
(\%)\end{array}$ & $\begin{array}{c}\text { The } \\
\text { Difference }\end{array}$ & $\begin{array}{l}\text { Significance of } \\
\text { the Differences }\end{array}$ & $\begin{array}{c}\text { Duncan } \\
\text { Classification }\end{array}$ \\
\hline E1 & Control Sample & 3.00 & 100.0 & 0.00 & Mt. & $\mathrm{D}$ \\
\hline E2 & Roots & 2.00 & 66.7 & -1.00 & 000 & $\mathrm{C}$ \\
\hline E3 & Leaves & 1.00 & 33.3 & -2.00 & 000 & $\mathrm{~B}$ \\
\hline E4 & Stems & 1.00 & 33.3 & -2.00 & 000 & $\mathrm{~B}$ \\
\hline E5 & Flowers & 0.67 & 22.2 & -2.33 & 000 & A \\
\hline & \multirow{3}{*}{\multicolumn{3}{|c|}{$\begin{array}{l}\text { SD (p 5\%) } \\
\text { SD (p 1\%) } \\
\text { SD (p 0.1\%) }\end{array}$}} & 0.24 & & \\
\hline & & & & 0.35 & & \\
\hline & & & & 0.53 & & \\
\hline
\end{tabular}

The differences of height registered in wheat plants (Table 2) show highly significant negative differences in all the cases in which aqueous extracts obtained from $T$. vulgare species were applied. The lowest values in plant height compared to the control sample were registered in variants E3, E4 and E5, the percentual differences ranging between $33.3 \%$ and $22.2 \%$. Highly significant negative differences were registered in variant E2.

\section{Results obtained on Barley (Hordeum vulgare L.)}

Regarding to the treatments made on barley seeds, the results obtained indicate highly significant negative differences in germination in variants E3 and E5, cases in which T. vulgare leaf and flower aqueous extracts were used; the germination differences were of $56.3 \%$, respectively of $46.8 \%$ compared to the control sample (Table 3), while in root and stem extract treatments, variant E2 and E4, the germination differences compared to the control sample were distinctly significant, respectively insignificant in variant E4.

Table 3

The Influence of Tanacetum vulgare extract on the Germination of Barley Seeds (Hordeum vulgare L.)

\begin{tabular}{|c|c|c|c|c|c|c|}
\hline $\begin{array}{c}\text { The } \\
\text { Symbol }\end{array}$ & $\begin{array}{l}\text { Type of } \\
\text { Extract }\end{array}$ & $\begin{array}{c}\begin{array}{c}\text { Number of } \\
\text { Germinated } \\
\text { Seeds }\end{array} \\
\end{array}$ & $\begin{array}{c}\begin{array}{c}\text { Percent of } \\
\text { Germinated } \\
\text { Seeds }\end{array} \\
\end{array}$ & The Difference & $\begin{array}{l}\text { Significance of } \\
\text { the Differences }\end{array}$ & $\begin{array}{c}\text { Duncan } \\
\text { Classification }\end{array}$ \\
\hline E1 & Control Sample & 84.00 & 100.0 & 0.00 & Mt. & $\mathrm{D}$ \\
\hline E2 & Roots & 80.67 & 96.0 & -3.33 & 00 & $\mathrm{C}$ \\
\hline E3 & Leaves & 47.33 & 56.3 & -36.67 & 000 & B \\
\hline E4 & Stems & 83.33 & 99.2 & -0.67 & - & D \\
\hline E5 & Flowers & 39.33 & 46.8 & -44.67 & 000 & A \\
\hline & \multirow{3}{*}{\multicolumn{3}{|c|}{$\begin{array}{l}\text { SD (p 5\%) } \\
\text { SD (p 1\%) } \\
\text { SD (p 0.1\%) }\end{array}$}} & 1.65 & & \\
\hline & & & & 2.40 & & \\
\hline & & & & 3.60 & & \\
\hline
\end{tabular}

In variants E3 and E5, where T. vulgare leaf and flower aqueous extracts were used, the height of barley plants indicate significant negative differences compared to the control sample, the percent values being of $60 \%$, while in variants E2 and E4 the differences were distinctly significant and significant. (Table 4)

Table 4

The Influence of Tanacetum vulgare extract on the Height of Barley Plants (Hordeum vulgare L.) after Springing

\begin{tabular}{|c|c|c|c|c|c|c|}
\hline $\begin{array}{c}\text { The } \\
\text { Symbol }\end{array}$ & Type of Extract & $\begin{array}{c}\text { Height of } \\
\text { Plants } \\
\text { (cm) }\end{array}$ & $\begin{array}{c}\text { Height of } \\
\text { Plants } \\
(\%) \\
\end{array}$ & $\begin{array}{c}\text { The } \\
\text { Difference }\end{array}$ & $\begin{array}{l}\text { Significance of } \\
\text { the Differences }\end{array}$ & $\begin{array}{c}\text { Duncan } \\
\text { Classification }\end{array}$ \\
\hline E1 & Control Sample & 5.00 & 100.0 & 0.00 & Mt. & $\mathrm{C}$ \\
\hline E2 & Roots & 4.00 & 80.0 & -1.00 & 00 & $\mathrm{~B}$ \\
\hline E3 & Leaves & 3.00 & 60.0 & -2.00 & 000 & A \\
\hline E4 & Stems & 4.33 & 86.7 & -0.67 & 0 & $\mathrm{~B}$ \\
\hline E5 & Flowers & 3.00 & 60.0 & -2.00 & 000 & A \\
\hline & \multirow{3}{*}{\multicolumn{3}{|c|}{$\begin{array}{l}\text { SD (p 5\%) } \\
\text { SD (p 1\%) } \\
\text { SD (p } 0.1 \%)\end{array}$}} & 0.49 & & \\
\hline & & & & 0.71 & & \\
\hline & & & & 1.06 & & \\
\hline
\end{tabular}




\section{Results obtained on Rape (Brassica napus L.)}

In what concerns the treatments made on rape seeds, the results obtained show highly significant negative differences compared to the control sample, the germination percentage being of only $5.6 \%$, respectively $4.8 \%$ in variants E3 and E5 where leaf and flower extracts were used, while in variant E2 and E4 the 98.4\% and 92.1\% germination percentage shows insignificant differences (Table 5).

Table 5

The Influence of Tanacetum vulgare extract on the Germination of Rape Seeds (Brassica napus L.)

\begin{tabular}{|c|c|c|c|c|c|c|}
\hline $\begin{array}{c}\text { The } \\
\text { Symbol }\end{array}$ & Type of Extract & $\begin{array}{c}\text { Number of } \\
\text { Germinated } \\
\text { Seeds }\end{array}$ & $\begin{array}{c}\text { Percent of } \\
\text { Germinated } \\
\text { Seeds }\end{array}$ & $\begin{array}{c}\text { The } \\
\text { Difference }\end{array}$ & $\begin{array}{l}\text { Significance of } \\
\text { the Differences }\end{array}$ & $\begin{array}{c}\text { Duncan } \\
\text { Classification }\end{array}$ \\
\hline E1 & Control Sample & 84.00 & 100.0 & 0.00 & Mt. & $\mathrm{B}$ \\
\hline E2 & Roots & 82.67 & 98.4 & -1.33 & - & $\mathrm{B}$ \\
\hline E3 & Leaves & 4.67 & 5.6 & -79.33 & 000 & A \\
\hline E4 & Stems & 77.33 & 92.1 & -6.67 & - & $\mathrm{B}$ \\
\hline E5 & Flowers & 4.00 & 4.8 & -80.00 & 000 & A \\
\hline \multicolumn{4}{|c|}{$\mathrm{SD}(\mathrm{p} 5 \%)$} & 6.70 & & \\
\hline \multicolumn{4}{|c|}{$\mathrm{SD}(\mathrm{p} 1 \%)$} & 9.75 & & \\
\hline & \multicolumn{3}{|l|}{$\mathrm{SD}(\mathrm{p} 0.1 \%)$} & 14.63 & & \\
\hline
\end{tabular}

The results obtained in the experiments made to determine the height of rape plants indicate highly significant negative differences in all variants tested, the focus being the results obtained in variants E3 and E5 (table 6), where T. vulgare leaf and flower extract treatments were used, cases in which the height of the plants was of only $10 \%$ compared to the control sample (Table 6).

Table 6

The Influence of Tanacetum vulgare extract on the Height of Rape Plants (Brassica napus L.) after Springing

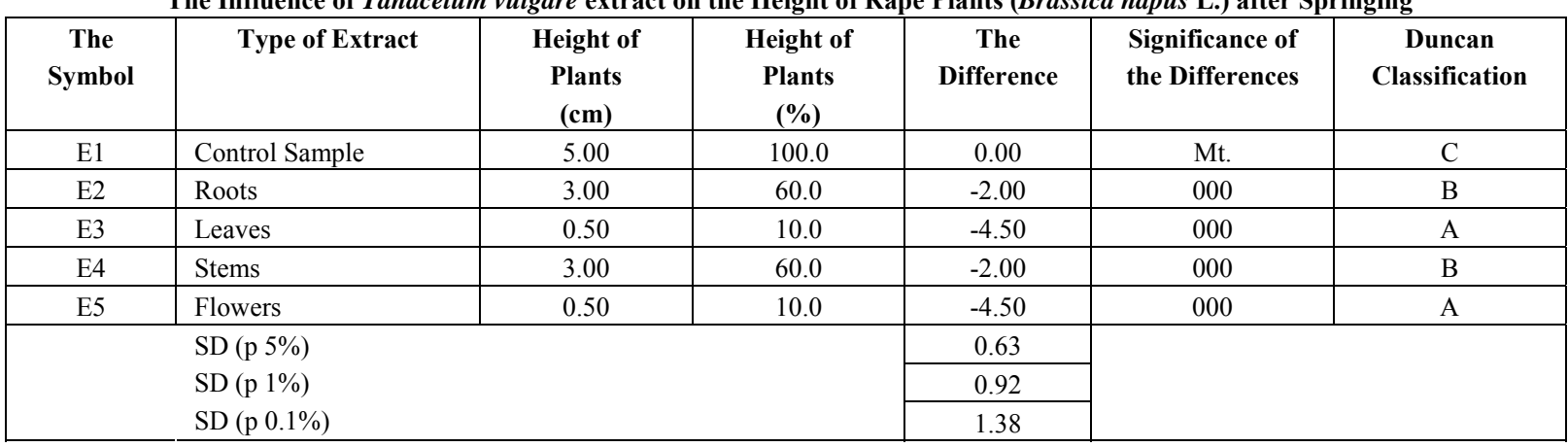

\section{CONCLUSIONS}

The results of the research involving T. Vulgare vegetative organ (root, leaf, stem, and flower) aqueous extracts indicate the presence of some chemical compounds with an allelopathic effect of inhibition.

In all tested variants, the aqueous extracts obtained from the species $T$. Vulgare showed negative influences both in the seed germination and in the growth of Triticum Aestivum L plants. The most inhibiting efect was registered in the case of leaf and flower aqueous extract treatments.

The species Hordeum Vulgare shows high sensitivity by inhibited germination and plant growth immediately after springing both in leaf and in flower aqueous extract treatments, the differences being highly significant negative.

In what concerns the treatments applied on Brassica Napus L., the results indicate in all tested variants highly significant negative influences on the height of the plants, distinctively in the cases where leaf and flower aqueous extracts were used, where as in germination the highly significant negative influences were registered in the treatments with leaf and flower aqueous extracts.

In all the experiments made on crop species like Triticum Aestivum L., Hordeum Vulgare L, Brassica Napus L., the leaf anf flower aqueous extracts obtained from $T$. Vulgare show a highly significant inhibiting influence both in the germination and in the growth of the the plants immediately after springing.

It is to be later studied, through nowadays modern techniques, which $T$. vulgare chemical compounds have such a strong manifestation and which are their usage possibilities. 


\section{REFERENCES}

BOZSA, R. C., OLIVER, L. R., (1993), Shoot and Root Interference of Common Cocklebur (Xanthium strumarium) and Soybean (Glycine max), Weed Science Society of America, volume 41:34-37.

CICEOI, R., (2005), Raport de cercetare, Revista de Politica Ştiinței şi Scientometrie - nr. special2005, ISSN - 1582-1218.

CORBU, C. S., (2007), Studierea fenomenului de alelopatie la plante, Teză de doctorat, Universitatea din Oradea.

DÁVID, I., BORBÉLYNÉ-VARGA, M., RADÓCZ, L., (2005), Néhány allelokemikália szintjének változása az olasz szerbtövisben (Xanthium italicum Mor.) a tenyészidőszak folyamán, Nővényvédelem 41 (9).

HODIŞAN, N., (2009), Results of the research on the alelopathic effect between the neophyte species, Iva xanthiifolia Nutt. (ierboaia) and some agricultural crops, The 8th International Symposium Prospects for the 3rd Millenium Agriculture, Cluj-Napoca.

RICE, E. L., (1974), Allelopathy, Ed., Academic Press, New York.

SINHA, N. K., SAMAR, J. S., (2004), Allelopathic effects of Xanthium strumarium on Parthenium hysterophorus, Indian Journal of Plant Physology vol. 9:313-315.

SONDHIA, S., SAXENA, N. K., (2003), Allelopathic effect of Xanthium strumarium L. on some weeds, Geobios, Jodhpur, Inde, vol. 30:173-176.

TANVEER, A., TAHIR, M., NADEEM, MA., YOUNIS, M., AZIZ, A., YASEEN, M., (2008), Allelopathic effects of Xanthium strumarium L. on germination and seedling growth of crops, Allelopathy Jurnal Departament of Agronomy University of Agriculture Faisalabed, Pakistan, vol. 21.

ULUDAG, A., UREMIS, I., ARSLAN, M., GOZCU, D., (2006), Allelopathy studies in weed science in Turkey - a review, Jurnal of Plant Diseases and Protection Zeitschrift fur Pflanzenkrankheiten und Pflanzenschutz Sonderheft XX, Stuttgart.

www.sfaturimedicale.ro 